International Journal of Linguistics, Literature and Translation

ISSN: 2617-0299 (Online); ISSN: 2708-0099 (Print)

DOI: 10.32996/ijltt

Journal Homepage: www.al-kindipublisher.com/index.php/ijltt

\title{
How Teachers Can Communicate Effectively with Parents Who Speak a Different Language
}

\author{
Adekunle Lawal 8(D) \\ Department of Teaching, Leadership \& Professional Practice at the University of North Dakota, United States of America \\ $\triangle$ Corresponding Author: Adekunle Lawal, E-mail: adekunle.lawal@und.edu
}

\author{
ARTICLE INFORMATION \\ Received: August 07, 2021 \\ Accepted: September 18, 2021 \\ Volume: 4 \\ Issue: 9 \\ DOI: 10.32996/ijllt.2021.4.9.17
}

\section{KEYWORDS}

effective communication, language barrier, interpreters, translation apps, parent-teacher conferences, Microsoft Translator, Google

Translate

\section{ABSTRACT}

Language differences between parents and teachers, if not carefully managed, can cause miscommunication or communication gaps that could hinder both the school's and students' progress. This paper explores various ways of translating real-time conversations between teachers and parents who speak a different language. Fourteen K-12 teachers in the United States were surveyed and nine were interviewed to determine how English-speaking teachers can communicate effectively with nonEnglish speaking parents. The findings from the study suggest Microsoft Translator technology for speech translation for conversations to break the language barrier, bridge communication gaps and promote effective bi/multilingual parent-teacher conferences.

\section{Introduction}

Communication between teachers and parents is essential to students' success at school. Parents rely on teachers' information about their kids' performance at school; teachers on their own part are readily to share the information about the kids' performance and other information which the school would like the parents to be aware of. But sometimes communication barriers make the passage of information ineffective. Few barriers, among others, are language, culture, values, economic status, illiteracy, and time constraints (Graham-Clay, 2005; Ozmen et al., 2016). Forty percent of immigrants in the United States were identified as having limited English proficiency (Batalova \& Zong, 2016; Lim et al., 2020).

The key obstacle to Hispanic parents in the United States becoming involved with the schools is the language barrier. The major language of Hispanics, who are also called Latinos, is Spanish. In most of the U.S. K-12 schools, teachers speak little or no Spanish, making communication about grades, behavior, or homework difficult (Chavkin \& Gonzalez, 1995; Gibson, 2002; Smith et al., 2008). The term "K-12" is used in the United States for Kindergarten to $12^{\text {th }}$ grade; this includes elementary, middle, and high schools (Corsi-Bunker, 2010; Lawal, 2020). Oftentimes, schools do not provide interpreters at parent meetings resulting in little understanding for Spanish parents (Scribner, Young \& Pedroza, 1999; Smith et al., 2008). When attempts by schools to translate documents into Spanish are made frequently, these attempts are based on the assumptions about the level of acculturation of parents, thus resulting in the loss of intended meanings. Also, when homework is assigned in English, many Hispanic parents are unable to help their children (Aspiazu, Bauer \& Spillett, 1998; Smith et al., 2008).

Hispanic/Latino parents often demonstrate low levels of involvement in their children's schools (Costas, 1991; Bauch, 1992; Smith et al., 2008). These parents care about their children's education, yet they do not become involved in their schools. A partial explanation of this paradox may be with the obstacles encountered by Latino parents: the language barrier, a lack of trust, a lack of understanding of the operation of school, logistical issues, and a lack of education of the parents themselves (Bauch, 1992; Smith et al., 2008).

\section{K C AL-KINDI CENTER R D FOR RESEARCH AND} Your gateway to world-class research

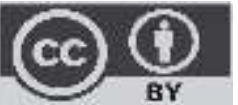

Published by Al-Kindi Center for Research and Development, London, United Kingdom. Copyright (c) the author(s). This open access article is distributed under a Creative Commons Attribution (CC-BY) 4.0 license 
Educators and researchers increasingly recognize the need for parents and teachers to collaborate to jointly guide and enhance the learning experiences of their children and students (Clark, 1987; Williams \& Cartledge, 1997). One major impediment to this collaborative effort is the lack of ongoing, effective parent-teacher communication (Williams \& Cartledge, 1997). Keyton (2010) defines communication as a process of transmitting information and common understanding from one person to another. The word communication is derived from the Latin word, communis, which means "common." The definition underscores the fact that unless a common understanding results from the exchange of information, there is no communication (Lunenburg, 2010).

Teachers strive to establish partnerships with parents to support student learning. Strong communication is fundamental to this partnership and to building a sense of community between home and school (Graham-Clay, 2005). Communication may involve impressions created or words expressed. Gestures such as a smile or lack of acknowledgement by office staff create strong impressions on some parents (Graham-Clay, 2005). Expressed communication involves one-way or two-way exchanges (Berger, 1991; Graham-Clay, 2005). One-way communication occurs when teachers seek to inform parents about events, activities, or student progress through a variety of sources, such as an introductory letter at the beginning of the school year, classroom or school newsletters, email, report cards, communication books, radio announcements, school web sites, and so on. Two-way communication involves interactive dialogue between teachers and parents. Conversations may occur during telephone calls, home visits, parent-teacher conferences, open houses, and various school-based community activities (Graham-Clay, 2005).

\section{Effective Parent-Teacher Communication}

Communication is a two-way process that requires effort and skill by the people involved (Lunenburg, 2010). Effective communication between parents and teachers or school authorities fosters a friendly learning environment. It also produces academic achievement and improvement by providing adequate support to parents, students, and teachers (Ozmen et al., 2016). How teachers gather information from parents is crucial to cordial communication and long-lasting relationship. Gathering information directly from parents is very helpful and may lead to a pragmatic and accurate understanding of the families, such as where to reach the families, who to contact, what issues the families are facing, and what potential barriers exist to their involvement. Perseverance in gathering family information and combining varied sources of information may also lead to a more comprehensive understanding of the families (Caspe, 2003). Furthermore, beliefs held by teachers may influence the amount and kinds of information they gather, the way they go about gathering it, and the meaning they make of it. When teachers believe that family information helps them better teach children, and that staying apprised of this information is part of one's job, teachers may have greater receptivity to families and initiative in seeking out information (Caspe, 2003).

When parents and teachers have rich and frequent communication, they can forge partnerships that produce benefits for children. Additionally, as the discourse between homes and schools increases, understanding improves, suggestions are shared, and positive attitudes are more easily maintained (Ames, Khoju, \& Watkins, 1993; Merkley et al., 2006). Effective communication opens the door for involvement. Parent involvement affects student motivation. Therefore, teachers have the greatest effect on both parent involvement and student motivation (Preciado, 2014).

School staff must determine with parents how they wish to communicate and how often they wish to communicate. Parents often have specific preferences. Consider the many ways that families differ before determining whether a home-school notebook, email or phone call is an effective form of communication. Most parents seek forums for communication that are ongoing, respectful, and lead to tangible improvements in their children's educational program (Davern, 2004). It is the role of school personnel to create a process that is inviting and meaningful for parents. Many parents will be responsive to such a process; others may prefer to have a less active role, and the perspective should be respected. The ability to participate may also change over time as parents' circumstances change (Davern, 2004). Many families may not find written forms of communication helpful. Some parents' first language is not English. Other parents who are English speakers may have reading difficulties. Even when school personnel can communicate in writing in languages other than English, parents may have reading difficulties in their first language (Al-Hassan \& Gardner, 2002; Davern, 2004).

\section{Language Barrier Contributes to Ineffective Communication}

For many parents, language is an insurmountable barrier to participation in their children's academic tasks. As their children progress through school, the content and course material become increasingly difficult to understand (Zarate, 2007). Most parents are interested in receiving more personalized, frequent, and timely information about their children's progress (Zarate, 2007; Quiocho \& Daoud, 2006). English-speaking parents are comfortable with email and web postings as avenues for communicating with teachers (Zarate, 2007). How would teachers communicate with non-English speaking parents? Some parents are educated and proficient in different languages rather than English (Smith, 2005; Poza et al., 2014). What channels of communication should teachers employ in reaching this group of parents? Research reveals language barrier in communication is one of the key obstacles faced by immigrant parents in the United States (Lim et al., 2019; Lim et al., 2020). How would educators overcome the language barrier between teachers and non-English speaking parents? 
There is another group of parents who cannot write or read in another language but are fluent in their native language (Smith, 2005; Poza et al., 2014). The language barrier identified between immigrant (Latino) parents and educators in Poza et al. (2014)'s study prompted me to conduct a study on how teachers and parents can overcome the language barriers that prevent them from having effective communication. The study's findings reveal how Latino parents were not pleased with how teachers and school administrators communicated information to them about their kids' performance in English without taking into consideration the fact that not all Latino parents could read in English. Furthermore, the parents complained of the school administration's insensitivity to their language differences; they claimed during parent-teacher conferences, teachers usually addressed the audience in English without Spanish interpreters for the Latino parents whose native language was Spanish (Poza et al., 2014).

\section{Research Question}

How can English-speaking teachers communicate effectively with non-English speaking parents?

Teachers and administrators in schools with large, working-class Latino populations often complain of parents' indifference or lack of involvement in children's schooling and this creates their low visibility at school events and relatively little face-to-face communication with teachers and school administration. From teachers' and schools' perspective, one of the most visible obstacles that immigrant Latino parents encounter in their efforts to participate in the school activities is language barrier (Poza et al., 2014; Smith et al., 2008). And because of this obstacle, non-English speaking Latino parents are reluctant to talk to teachers or school administrators if there is a problem at school or they want to have confidential conferences with the teachers about their kids' academic performance. It would be awkward to have such meetings since they use their kids as interpreters whenever they want to communicate with the school officials (Smith et al., 2008).

The language barrier, among other factors, makes non-English speaking Latino parents less visible in the school activities, and this leads to some teachers holding the wrong notion about Latino parents as people who are not interested in their kids' education. How can English speaking teachers and non-English speaking parents work together to overcome the language barrier which prevents them from having robust and effective communication?

\section{Purpose and Methodology}

The purpose of the study was to identify a practical solution to the issue of the language barrier which contributes to ineffective communication between English speaking teachers and non-English speaking parents in the United States. The findings from this study should benefit schools, parents, and teachers around the world; especially in situations where teachers and parents cannot communicate effectively because of language differences. For instance, taking examples from different settings, the language barrier could cause ineffective communication between Russian speaking teachers and non-Russian speaking parents, Chinese speaking teachers and non-Chinese speaking parents, or Arabic speaking teachers and non-Arabic speaking parents, and so on. The United States' setting is used as a case study in this paper to illustrate how the language barrier can be a major obstacle to effective communication between parents and teachers.

Survey and interview were used to collect data. The survey covered five multiple-choice questions (Table 1). The survey exclusively targeted American teachers: the questions were intended for only K-12 teachers in the United States. The study focused on how English-speaking teachers can communicate effectively with parents who speak languages other than English.

Table 1. Teacher-Parent Communication Survey

Teacher-Parent Communication Survey

1. What level of students do you currently teach? (please select all that apply)

Elementary school students

Middle school students

High school students

2. Are you a school administrator?

Yes

No

3. How do you pass information to the students' parents? (please select all that apply)

Through written notes

Phone call

Email

School website 


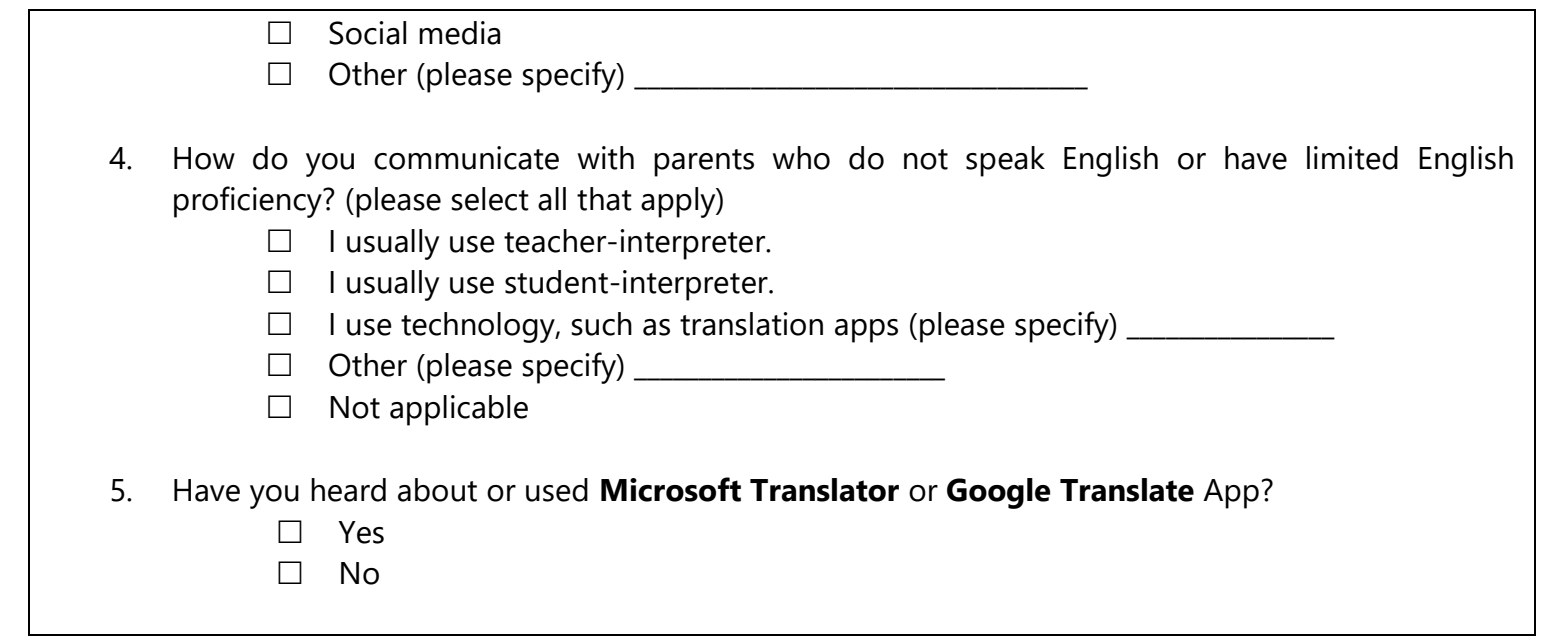

The one-page survey was created using Qualtrics Survey Software; its generated link was shared through social media - Twitter $\&$ Linkedln while the printed copies were handed out.

An interview was conducted to gather more information on how teachers communicate with the parents. The interview was conducted in a semi-structured setting (Fauvelle, 2020). This type of interview creates the opportunity for the respondents to ask questions and talk freely on the topic under discussion; it also gives the opportunity to the researcher to probe and clarify any issues that might have come up during the interview. The teachers that participated in the interview were among those that completed the survey.

\section{Findings}

\subsection{Survey}

The instruction attached to the survey link posted on Twitter and Linkedln stated the survey was for only active K-12 teachers in the United States. The survey software that was used had a feature that helped tracked the location of the respondents when completing the survey. All the completed survey, both printed copies and those that were completed on social media, came from respondents who lived in Texas, Washington, North Dakota, and Minnesota states. In total, 14 respondents completed and returned the survey: 3 middle school teachers, 3 high school teachers and 8 elementary school teachers (Table 2). 6 teachers among the 14 respondents identified themselves as school administrators. In this paper, the term "teachers" is used for both school administrators and classroom teachers.

Based on the data collected, table 2 shows breakdown of teachers' preferred methods of communication when passing information to parents.

Table 2. How do teachers pass information to parents?

\begin{tabular}{|c|c|c|c|c|c|c|}
\hline Teachers & $\begin{array}{l}\text { Through written } \\
\text { notes }\end{array}$ & $\begin{array}{l}\text { Phone } \\
\text { call }\end{array}$ & Email & $\begin{array}{l}\text { School } \\
\text { website }\end{array}$ & $\begin{array}{l}\text { Social } \\
\text { media }\end{array}$ & Other \\
\hline $\begin{array}{l}\text { Elementary school } \\
\text { teachers (8) }\end{array}$ & $\begin{array}{l}5 \\
(62.5 \%) \\
\end{array}$ & $\begin{array}{l}7 \\
(87.5 \%) \\
\end{array}$ & $\begin{array}{l}7 \\
(87.5 \%) \\
\end{array}$ & $\begin{array}{l}3 \\
(37.5 \%)\end{array}$ & $\begin{array}{l}3 \\
(37.5 \%) \\
\end{array}$ & $\begin{array}{l}5 \\
(62.5 \%) \\
\end{array}$ \\
\hline $\begin{array}{l}\text { Middle school teachers } \\
\text { (3) }\end{array}$ & $\begin{array}{l}1 \\
(33.3 \%)\end{array}$ & $\begin{array}{l}3 \\
(100 \%)\end{array}$ & $\begin{array}{l}3 \\
(100 \%)\end{array}$ & $\begin{array}{l}3 \\
(100 \%)\end{array}$ & $\begin{array}{l}3 \\
(100 \%)\end{array}$ & $\begin{array}{l}1 \\
(33.3 \%)\end{array}$ \\
\hline $\begin{array}{l}\text { High school teachers } \\
\text { (3) }\end{array}$ & $\begin{array}{l}0 \\
(0 \%)\end{array}$ & $\begin{array}{l}3 \\
(100 \%)\end{array}$ & $\begin{array}{l}3 \\
(100 \%)\end{array}$ & $\begin{array}{l}2 \\
(66.7 \%)\end{array}$ & $\begin{array}{l}1 \\
(33.3 \%)\end{array}$ & $\begin{array}{l}0 \\
(0 \%)\end{array}$ \\
\hline
\end{tabular}

The data from table 2 reveals phone calls and email as $\mathrm{K}-12$ teachers' most preferred methods of communication; $87.5 \%$ of surveyed elementary school teachers and $100 \%$ of surveyed middle school and high school teachers have used phone calls and email for passing information to parents. Written notes as a method of communication are largely used among elementary 
school teachers; $62.5 \%$ of surveyed elementary school teachers have used written notes for passing information to parents. However, this method of communication was less used among surveyed middle school teachers (33.3\%) and high school teachers (0\%).

Nevertheless, $62.5 \%$ of surveyed elementary school teachers, $33.3 \%$ of middle school teachers and $0 \%$ of high school teachers have used "other" methods of communication for passing information to parents (Table 2). These "other" methods of communication identified by the teachers were school-provided communication apps like Dojo, Remind, Skyward, and Preschool2me. One of the teachers mentioned Zoom as an alternative app for communication.

Table 3. How do English-speaking teachers communicate with non-English speaking parents?

\begin{tabular}{|l|l|l|l|l|l|}
\hline Teachers & $\begin{array}{l}\text { Teacher- } \\
\text { interpreter }\end{array}$ & $\begin{array}{l}\text { Student- } \\
\text { interpreter }\end{array}$ & $\begin{array}{l}\text { Technology } \\
\text { (Translation } \\
\text { apps) }\end{array}$ & $\begin{array}{l}\text { Other (e.g., } \\
\text { Bilingual) }\end{array}$ & Not applicable \\
\hline $\begin{array}{l}\text { Elementary school } \\
\text { teachers (8) }\end{array}$ & $\begin{array}{l}6 \\
(75 \%)\end{array}$ & $\begin{array}{l}2 \\
(25 \%)\end{array}$ & $\begin{array}{l}5 \\
(62.5 \%)\end{array}$ & $\begin{array}{l}2 \\
(25 \%)\end{array}$ & $\begin{array}{l}1 \\
(12.5 \%)\end{array}$ \\
\hline $\begin{array}{l}\text { Middle school teachers } \\
(3)\end{array}$ & $\begin{array}{l}1 \\
(0 \%)\end{array}$ & $\begin{array}{l}3 \\
(33.3 \%)\end{array}$ & $\begin{array}{l}1 \\
(100 \%)\end{array}$ & $\begin{array}{l}0 \\
(33.3 \%)\end{array}$ \\
\hline $\begin{array}{l}\text { High school teachers } \\
(3)\end{array}$ & $\begin{array}{l}1 \\
(33.3 \%)\end{array}$ & $\begin{array}{l}1 \\
(33.3 \%)\end{array}$ & $\begin{array}{l}1 \\
(33.3 \%)\end{array}$ & $\begin{array}{l}1 \\
(33.3 \%)\end{array}$ \\
\hline
\end{tabular}

The collected data reveals various strategies of communication that English-speaking teachers have employed to converse with parents who speak languages other than English. The surveyed elementary school teachers (75\%) favored teacher-interpreter as a way of communicating with parents who speak other languages. However, this method of communication was not a favorite of surveyed middle school teachers (0\%) and high school teachers (33.3\%). Student-interpreter was fairly used for communication; $25 \%$ of the elementary school teachers, $33.3 \%$ of middle school teachers and $33.3 \%$ of high school teachers have used student interpreters (Table 3). The "other" ways of communication, for instance, being a bilingual teacher was mentioned as a viable way of communication. Few among the surveyed teachers could speak both English and Spanish fluently; $25 \%$ of the elementary school teachers, 33.3\% of the middle school teachers and 33.3\% of high school teachers were bilingual teachers. This data corroborates with literature and research that claim few English-speaking teachers in K-12 schools in the United States speak Spanish (Chavkin \& Gonzalez, 1995; Gibson, 2002; Smith et al., 2008). Nonetheless, some surveyed teachers claimed they never had occasion where they needed to converse with parents who do not speak English; $12.5 \%$ of the surveyed elementary school teachers, $0 \%$ of the middle school teachers and $33.3 \%$ of the high school teachers selected "not applicable" as a response to the question, what method do they use when conversing with parents who do not speak English (Table 3).

However, teachers have started using technology (Translation apps) as a way of communicating with non-English speaking parents. $62.5 \%$ of surveyed elementary school teachers, $66.7 \%$ of middle school teachers and $33.3 \%$ of high school teachers have considerably used translation apps when conversing with non-English speaking parents (Table 3). Regarding the translation apps for translating texts, documents or webpages, the surveyed teachers mentioned apps like Dojo, Preschool2me, Remind, Google Translate and Microsoft Translator. In addition, the identified translation apps for conversing were Voiance, Google Translate and Microsoft Translator.

\subsection{Interview}

9 teachers among the 14 surveyed teachers were selected for the interview. The teachers were selected based on their responses to the "technology" prompt from question four on the survey. 6 out of the 9 teachers were conversant with translation apps for conversing with non-English speaking parents. The other 3 teachers were skeptical about the efficacy of translation apps. The semi-structured interview was conducted in a setting where teachers talked freely about their experiences of using translation apps when communicating with non-English speaking parents. The interview was held in a one-on-one meeting with each teacher.

Each teacher responded to the given prompts in unique ways. These are the interview questions:

1. Briefly describe your experience using translation apps as a medium of communication with non-English speaking parents.

2. Have you ever used Google Translate or Microsoft Translator for conversations? 
3. Do you think Google Translate or Microsoft Translator app is useful and efficient for parent-teacher conferences? Below are responses from the three teachers who favored human interpreters over translation apps for conversations.

Teacher 1 (High school teacher):

I have heard and seen teachers using translation apps for parent-teacher conferences. I have never tried any of the available apps for translation. Whenever I held conferences with non-English speaking parents, I always called on my students to help in translating. Most of the parents I encountered were Hispanics. Although I used Google Translate on couple of times to check English of some Spanish words, but I have never used it to write email to parents or translate documents. And I have never tried Google Translate for conversation or Microsoft Translator for conversing with parents. Do they [translation apps] really work? Can the apps translate efficiently like humans? I prefer using the service of my student-interpreters for now.

Teacher 2 (Middle school teacher):

I have held many parent-teacher conferences with parents who speak languages other than English. During these meetings, I used school-contracted hired interpreters called Voiance. Voiance is a human-interpreters translation agency, they serve as intermediary between their clients and guests who speak a different language. Their interpreting service is like the service rendered by the teacher-interpreters or studentinterpreters. With the assistance of Voiance interpreters, I held many conferences on phones on the school ground or remotely with parents who do not speak English fluently. Moreover, I use Voiance interpretation service to communicate celebrations, conferences and [students'] behavioral concerns to parents. I have used Google Translate for translating texts and documents, but I have not used it for conversations. I use Voiance interpreters for all my conversational translations. I have not used Microsoft Translator for translating texts, documents, or conversations.

Teacher 3 (Elementary school teacher):

I usually call on our teacher-interpreters to interpret for me. We have dedicated bilingual teachers in my school. Most of the non-English speaking parents I held conferences with were Hispanics. Sometimes, if the bilingual teachers were busy, I usually asked some of my Latino students to interpret for me. I have used Google Translate to find English words of some Spanish words I came across while reading for lesson preparations. I have not used Google Translate for conversation or Microsoft Translator for conversing with parents. I am comfortable with the school resources [bilingual teachers and student-interpreters] for translation. I heard these so-called translation apps are not always accurate, right?

Below are responses from teachers who favored translation apps for conversations over human interpreters. Since the six teachers who favored translation apps gave slightly similar statements, I decided to select statements from three teachers that could represent all six.

Teacher 4 (Elementary school teacher):

My school provided communication software called Dojo app for all the teachers. I communicate with parents through Dojo. The software has a translation feature that I regularly use when communicating with nonEnglish speaking parents. The app can translate many foreign languages like Spanish, German, Dutch, French and others to English. I have used it on many occasions to write and respond to emails sent to me in Spanish. I have also used it to translate documents. While the app is useful for translating texts, it cannot be used for conversations. I have used both teacher-interpreters and student-interpreters for parent-teacher conferences. I rarely use Google Translate for translating texts since I have Dojo app at my fingertips. Sometimes, I use Google Translate for webpage and documents translations, I think Google Translate does a better job with translating documents. I have not used Google Translate for conversations. I have not also tried Microsoft Translator for translating texts, documents, or conversations. Although my colleagues told me Microsoft Translator is a good app for conversations and conferencing, I intend to try it one of these days.

Teacher 5 (Elementary school teacher):

Being an administrator, I have held several parent-teacher conferences with non-English speaking parents. Although I speak Spanish moderately, not fluently, I used teacher-interpreters for parent-teacher conferences 
to avoid misinformation during important conversations. I have used Google Translate for translating texts, webpages, and documents, but not for conversations. I have not tried Microsoft Translator for translating texts and documents. But I have involved using Microsoft Translator for conversations few times with an owner of a massage place. She was a Chinese woman. Whenever I visit for massaging, she would bring out her mobile phone which has an installed Microsoft Translator app for conversation. I speak towards the phone in English, and the AI [Artificial Intelligence] in the phone will translate and speak out my words to the woman in Chinese. The woman also responds by speaking towards the phone in Chinese, the Al in the phone will translate the words and speak them out to me in English. This how we transact the business each time I visit the place. It is just amazing!

Teacher 6 (High school teacher):

I frequently hold parent-teacher conferences with non-English speaking parents. I have used both Google Translate and Microsoft Translator for translating texts and documents. Google Translate does better in translating texts and documents. But Microsoft Translator is your best bet for accurate voice translations. Most non-English speaking parents that I held conferences with were Hispanics, the Spanish translation of Microsoft Translator for conversation is excellent. Parents have nothing to do than to speak towards my mobile phone which has an installed Microsoft Translator app. With "interpreter mode" being switched on, I press once the speaker button for conversation on the phone, and the conference begins. For Hispanic parents, I usually select English and Spanish languages for translation, and the software automatically detects and picks up the languages as we speak. I speak English towards the phone, the app in the phone interprets and speaks out my words in Spanish; my Hispanic guests respond by speaking Spanish towards the phone, the app in the phone interprets and speaks out the message in English. This is how I comfortably hold my parent-teacher conferences with non-English speaking parents. And the parents told me they found the app very useful; language barrier is no more a problem.

The findings from this study reveal how K-12 teachers in the United States strive to create and establish effective communication between them and non-English speaking parents. All the teachers surveyed and interviewed demonstrated their willingness in communicating information to parents in an efficient manner. They recognized vital inputs parents contribute to students' academic improvements and school development.

While the surveyed teachers showed interest in effective communication with parents who speak a different language, only $64.3 \%$ (9 out of 14) of the teachers further showed interest in using technology as additional or sole method of communication. And out of the nine tech-inclined teachers, only $66.7 \%$ (6 out of 9) favored translation apps as suitable method of communication with non-English speaking parents.

\section{Technology and Effective Communication}

Technology has been the applications used to achieve goals faster and in more simplified manners. Since technology literacy is at the core of $21^{\text {st }}$ century skills (Voogt \& Roblin, 2010), school districts are constantly changing and improving the ways teachers communicate with parents (Tyson, 2020). The new trend in digital communication has replaced the traditional use of communicating through paper, so much that school districts now encourage parent-teacher communication through technology (Ho et al., 2013; Tyson, 2020). For family-school partnerships to fully benefit from technology, both parents and teachers must be willing to embrace technology as a communication tool (Rogers \& Wright, 2008).

There are four major types of communication: verbal, non-verbal, written, and visual (Indeed Career Guide, 2021). Teachers and parents could exchange information through any of these ways of communication. In this paper, focus will be on verbal communication; how English-speaking teachers can verbally communicate (converse) effectively with non-English parents. There are two possible means, among others, that teachers use when they need the service of speech translation - human interpreters and translation apps. Few human interpreters were already mentioned: teacher-interpreters, student-interpreters and hired interpreters (e.g., Voiance). Two speech translation apps were also mentioned: Google Translate and Microsoft Translator.

Some essential benefits of translation apps over human interpreters make the software appealing for speech translation (Table 4). 
Table 4. Translation Apps vs. Human Interpreters

\begin{tabular}{|l|l|}
\hline Translation Apps & Human Interpreters \\
\hline $\begin{array}{l}\text { Translation app is readily available once it is installed on } \\
\text { mobile phones or other digital devices. }\end{array}$ & $\begin{array}{l}\text { Human interpreters are not readily available. } \\
\text { Interpreters need to be invited or hired. }\end{array}$ \\
\hline $\begin{array}{l}\text { Translation apps like Google Translate and Microsoft } \\
\text { Translator are free for downloading. }\end{array}$ & $\begin{array}{l}\text { Translation service by hired interpreters is very } \\
\text { expensive. }\end{array}$ \\
\hline $\begin{array}{l}\text { Users do not need to have the knowledge of language } \\
\text { of their guests. }\end{array}$ & $\begin{array}{l}\text { Interpreters need to have good knowledge of the } \\
\text { language invited to interpret. }\end{array}$ \\
\hline $\begin{array}{l}\text { No risk of divulging confidential reports. } \\
\text { language conference of speakers of more than ten } \\
\text { different languages at a time. }\end{array}$ & $\begin{array}{l}\text { Teachers feel reluctant to use students as interpreters } \\
\text { for sensitive discussions about other students. }\end{array}$ \\
\hline
\end{tabular}

Sources: Microsoft Corporation (2021); Google Liability Limited Company (2021); Voiance (2021)

Based on the data collected, 42.9\% (6 out of 14) surveyed and interviewed teachers favored technology or speech translation apps as suitable tools for translating speech conversations with non-English parents. Moreover, $100 \%$ (14 out of 14 ) teachers acknowledged they have heard about Google Translate or Microsoft Translator, and 92.9\% (13 out of 14) teachers have used either Google Translate or Microsoft Translator for translating texts or documents. While various avenues are available for teachers to employ for speech translation, translation apps have started getting noticed as viable tools for breaking language barrier that usually creates communication gaps between teachers and parents.

To answer the research question, how can English-speaking teachers communicate effectively with non-English speaking parents? I would suggest speech translation apps like Microsoft Translator for Conversation, a practical and powerful tool, for holding an effective parent-teacher conferences. Google Translate App can also be used for translating conversations, but there are some unique features in Microsoft Translator App that make it more suitable for speech conversations (Table 5).

Table 5. Microsoft Translator App vs. Google Translate App

\begin{tabular}{|l|l|}
\hline Microsoft Translator App & Google Translate App \\
\hline $\begin{array}{l}\text { Microsoft Translator App has more languages for real- } \\
\text { time speech translations (47 languages, as of } \\
\text { September 2021). }\end{array}$ & $\begin{array}{l}\text { Google Translate App has fewer languages for real-time } \\
\text { speech translations (32 languages, as of September } \\
2021) \text {. }\end{array}$ \\
\hline $\begin{array}{l}\text { The app accommodates up to } 100 \text { people having real- } \\
\text { time chats and speech conversations in multiple } \\
\text { languages. }\end{array}$ & $\begin{array}{l}\text { The app accommodates only } 2 \text { people at a time having } \\
\text { real-time chats and speech conversations in two } \\
\text { different languages. }\end{array}$ \\
\hline $\begin{array}{l}\text { Users can engage in speech conversations or } \\
\text { conferences in different languages on smartphones } \\
\text { (Androids, iPhones, etc.), iPads, tablets, and computers } \\
\text { (Windows, Mac, etc.). }\end{array}$ & $\begin{array}{l}\text { Users cannot hold voice conversations or speech } \\
\text { conferences on computers. The app only works on } \\
\text { smartphones (Androids, iPhones, etc.), iPads and } \\
\text { tablets. }\end{array}$ \\
\hline $\begin{array}{l}\text { Its compatibility with computers makes it practical and } \\
\text { convenient to use for real-time speech conversation } \\
\text { and translation during large audience events like } \\
\text { parent-teacher conferences (family night, open house, } \\
\text { multi-cultural events). }\end{array}$ & $\begin{array}{l}\text { The app cannot be used for real-time speech } \\
\text { conversation and translation in large gathering events. }\end{array}$ \\
\hline $\begin{array}{l}\text { When real-time voice conversations and translation take } \\
\text { place on computers, eye-contact is feasible. }\end{array}$ & $\begin{array}{l}\text { It is difficult to make eye-contact when having real-time } \\
\text { voice conversations and translation on mobile phones. }\end{array}$ \\
\hline
\end{tabular}

Sources. Microsoft Corporation (2021); Google Liability Limited Company (2021)

While the surveyed/interviewed teachers mostly preferred Google Translate for translating texts and documents, Microsoft Translator was their favorite choice for speech translation during conversations or conferences (Teachers 4, $5 \& 6$ ). One of the teachers interviewed claimed she once used Google Translate for a text-to-speech conversation with a parent who spoke a different language. According to her, the experience was awkward and stressful; both partners found it difficult to understand 
each other. Eventually, the teacher had to call a teacher-interpreter to interpret their conversation. The awareness of Microsoft Translator as a powerful speech translation app needs to be widely spread among educators.

\section{Microsoft Translator for Education}

Microsoft Corporation is the manufacturer of Microsoft Translator. The company had educators, students and their parents in mind when building the valuable app. Education has witnessed various strategies to tackle the issue of language barrier that creates communication gaps between teachers and parents who speak a different language. Microsoft Translator provides practical and viable way of communicating to bridge the communication gaps. The app not only useful for parent-teacher conferences but also improves teaching and learning in the classroom. Schools are increasingly diverse (Zarate, 2007). Teachers manage many types of leaners, including students who are deaf or hard of hearing (DHH) who require assistive technology, dyslexic, having trouble taking notes and language learners (and their parents) who may not speak or understand the language of the classroom. Microsoft Translator helps bridge these communication gaps, supporting accessible classroom learning with live captioning, cross-language understanding, and even multilingual casual conversations to help with student integration (Microsoft Corporation, 2021; Lake \& Beisly, 2019).

Using translation apps [such as Microsoft Translator] for translating classroom instructions, directions, assignments, and homework can help ELLs (English Language Learners) transfer first language skills into their second language and communicate better (Goodwin \& Jimenez, 2016; Perozzi \& Chavez-Sanchez, 1992; Lake \& Beisly, 2019). The ability to translate information in real time may be particularly helpful for newcomer children who may not have the opportunity to express themselves otherwise (Yi \& Choi, 2015; Lake \& Beisly, 2019). Translation apps can help facilitate communication between teacher and child, especially when the teacher does not speak the child's home language (Prince, 2017; Lake \& Beisly, 2019). Children can also use translation apps to communicate with each other, for example, discussing and sharing information gathered individually (Liu et al., 2014; Lake \& Beisly, 2019). Reconceptualizing learning using translation apps [like Microsoft Translator] is one way schools and teachers increase communication, learning, and engagement of ELLs (Lake \& Beisly, 2019).

Microsoft Translator is a free downloadable app and easy to use. It can be used from a desktop, laptop, tablet, or smartphone. It is available on windows, mac, iOS, and androids. The app is suitable for conversations (chats, conferences, etc.). Users who speak different languages need not worry of translations, as the app detects and translates their conversations. For those users who do not want to download the translator app on their devices, Microsoft Translator is readily available on the web for their use. By typing https://translator.microsoft.com/ inside your browser and search, the search engine will bring up the website for Microsoft Translator for Conversation. One may also simply search for "Microsoft Translator for Conversation"; the search result will be the same. The website has features for users to join or start a conversation and select a language of their choice for conversation (Microsoft Corporation, 2021). Accessibility to this website opens a door of opportunity for conversing for free in different languages through a powerful translation tool. Since most schools do not allow their students to use mobile phones in classrooms, Microsoft Translator on the web, which can be accessed from a desktop, laptop, tablet, or iPad, will be suitable for students.

Microsoft Translator can be used across multiple devices. One person can be using the translator from a desktop computer or laptop and the other person on a mobile device, and both partners will be having a meaningful conversation. The translator translates texts and voices at the same time; users hear the translated conversations and read the texts in their own languages as other users are speaking or texting in a different language. Microsoft Translator can be used for one-on-one chats, bi/multilingual conferences, and large group interactions (Microsoft Corporation, 2021).

The following instructions help users (hosts) to operate Microsoft Translator on several devices (Microsoft Corporation, 2021):

For Microsoft Translator on iOS (iPhone, iPad) or Android (smartphone)

- $\quad$ Download the free Microsoft Translator app from your device's app store, then open the Translator app.

- $\quad$ Select the conversation icon (the icon that depicts two people talking).

- Under "Start conversation", select Start.

- $\quad$ Enter your name in the field labeled "Your name", select your language in the "Your language" menu, and then select Enter.

- $\quad$ Copy the Conversation code (Join code) and select Enter. Share that code with the parent(s).

- $\quad$ After selecting Enter, the conversation session will open.

- Speak or type in your own language; the conversation will be translated into the preferred language of the other party.

For Microsoft Translator on a desktop, laptop, or tablet 
- Start your browser, go to the Microsoft Translator Conversation web (https://translator.microsoft.com/), and select the tab titled Start conversation.

- Sign in. Enter your name in the field labeled "Your name", select your language in the "Your language" menu, and then select Enter.

- Depending on your setup, you might be asked to test your microphone to make sure things are working.

- After selecting Enter, the session will begin, and you will be shown a Conversation code (Join code) that looks like $A B C D E$ and a QR code. Share that code with the parent(s) you have invited. You can do this by sharing your screen or sending a text with the code to the parent(s).

- As session begins, you can turn on Presenter mode so that you can talk freely.

- Speak or type in your own language; the conversation will be translated into the preferred language of the other party.

- If you are in a noisy environment, it is recommended you use a headset for quality sound.

2021):

To get a good and quality performance from the Translator, take note of the following tips (Microsoft Corporation,

- If you are using a headset with a computer, hold the microphone close to your mouth. The translator conversation feature works best when you wear a mic close to the mouth, since it reduces background noise and effect of reverberation while speaking.

- Focus on proper articulation (no mumbling) and pause between sentences so the system can catch up (it waits for a pause to finalize the translation). If you follow these instructions, there is no need to speak slowly.

- Avoid very short or very long sentences. The system (both for speech recognition and translation) uses context of a full sentence. By providing more context, you will increase the chances for both to work better. Ideally, sentences between 5 and 15 words are perfect.

- Avoid unusual people and place names, if possible. Also avoid foreign place names. So, for instance, while speaking English, cities like Seattle or Milan will work fine. However, Klahanie or Milano might not.

- If you are bilingual, do not switch languages. Translator will only understand the language you chose.

- A strong WiFi, wired, or data connection is important - and so is a quiet room. Microsoft Translator requires access to the cloud, and it is best to have a good connection and very little background noise.

- Lastly, if you have a parent join the conversation from their device, be sure in advance that they have a compatible device (smartphone (Android), iOS (iPhone, iPad), tablets and Chromebook, and Chrome, Firefox, Safari or Edge browser).

Microsoft Translator is built to conquer the problem of the language barrier that usually brings misinformation and communication gaps. Having adequate preparations and good knowledge of how to use the Translator make all parties involved in chats/conferences feel relaxed and enjoy free-flowing translated conversations.

\section{Conclusion}

Integrating technology into the methods of communication enriches how parents and teachers communicate. Using technology to support teacher-to-parent and school-to-parent communication has gained significant momentum in the last decade (Rainie \& Smith, 2013; Beecher \& Buzhardt, 2016). The use of mobile devices across all facets of life is expanding exponentially. As the costs of technology decrease and the general public's familiarity and acceptance of technology increases, there has been a significant upsurge in the use of mobile devices and internet-enabled tools (Beecher \& Buzhardt, 2016). Based on a survey conducted in Spring of 2013, Pew Research reported that cell phone ownership in the United States reached 91\%, making it the fastest consumer technology to achieve that adoption rate. In the same survey, 56\% of respondents reported owning a smartphone, which provides access to the Internet and enables use of apps. Among African Americans and Hispanics, smartphone use is estimated to be higher (64\% and 60\% respectively) than Whites (53\%) (Rainie, 2013; Beecher \& Buzhardt, 2016). The use of tablets and e-readers has increased from 6\% in 2010 to 43\% in September 2013 (Smith, 2013; Beecher \& Buzhardt, 2016).

In today's high stakes educational environment, teachers have a lot of demands on their time and priorities. Likewise, parents have much to juggle in their daily lives. To create an optimal environment that supports authentic parent engagement, the right tools and curriculum might not be sufficient; usability and feasibility are essential for the success of any parent engagement program using technology (LaRocque et al., 2011; Beecher \& Buzhardt, 2016). For parents, using a smartphone app like Microsoft Translator put the engagement tool into something they used heavily throughout the day, and could check in less than two minutes was key to making it something they would use (Beecher \& Buzhardt, 2016). In a pilot study conducted by Beecher \& Buzhardt (2016), Spanish-speaking parents indicated that they felt the installed app on their smartphones increased their ability to communicate with the teacher. According to the researchers, easy to use translation support would be essential to reach the families who may most benefit from increased engagement with their child's school. 
Since mobile device like smartphones are commonly accessible for non-English speaking parents (Rainie, 2013; Beecher \& Buzhardt, 2016), then using installed Microsoft Translator for communicating with teachers should promote effective communication and long-lasting relationship between parents and teachers, and this invariably contributes to the child's academic improvement. Using the Microsoft Translator app, a non-English speaking parent could send a conversation code to an English-speaking teacher and request for a conversation regarding her child's progress at school. When the teacher receives the code, she could arrange for a conversation on the Microsoft Translator. The parent does not need to leave her house to hold the meeting if both parties engage in the conversation on Microsoft Translator. Both the English-speaking teacher and non-English speaking parent will hear and read the conversations in their own language as they speak and text in a different language. On the other hand, an English-speaking teacher could also initiate the conversation by sending a conversation code to a nonEnglish speaking parent. The conversation could be a chat or conference.

In a situation where a non-English parent does not have a smartphone or not conversant with the translator, the Englishspeaking teacher should try and invite the parent to the school ground. The teacher should be prepared to provide an extra device for the parent. Using Microsoft Translator for translating real-time conversations during parent-teacher conferences eliminates anxiety about the language barrier and promotes effective communication between teachers and parents who speak a different language.

\section{Recommendations}

\subsection{Recommendations for teachers}

- Teachers should create time to study how Microsoft Translator works.

- They should encourage school administration to install the software on their classroom desktop computers or laptops.

- Teachers should help parents who speak a different language understand how the Translator works.

- $\quad$ They should have extra digital devices available for parents who do not have compatible devices.

\subsection{Recommendations for parents}

- $\quad$ Parents should install Microsoft Translator app on their smartphone.

- $\quad$ They should create time to study how the installed Translator works.

- $\quad$ Parents should not wait until teachers invite them for conference; they can also initiate the meeting.

\section{References}

[1] Al-Hassan, S., \& Gardner, R. III, (2002). Involving immigrant parents of students with disabilities in the educational process. TEACHING Exceptional children, 34(5), 52-58.

[2] Ames, C., Khoju, M., \& Watkins, T. (1993). Parents and schools: The impact of school-to-home communications on parents' beliefs and perceptions. (Report No. 15). Baltimore, MD: Johns Hopkins University, Center on Families, Communities, Schools, and Children's Learning.

[3] Aspiazu, G.G., Bauer, S.C., \& Spillett, M.D. (1998). Improving the academic performance of Hispanic youth: A community education model. Bilingual Research Journal, 22(2), 1-20.

[4] Batalova, J., \& Zong, J. (2016, November 10). Language Diversity and English Proficiency in the United States. Retrieved from https://www.migrationpolicy.org/article/language-diversity-and-english-proficiency-united-states

[5] Bauch, P.A. (1992). Toward an Ecological Perspective on School Choice. Paper presented at the Annual Meeting of the American Educational Research Association, San Francisco, April 20. ED346595.

[6] Beecher, C., \& Buzhardt, J. (2016). Mobile technology to increase parent engagement. Interaction Design and Architecture(s) Journal (IxD\&A), 28, 49-68.

[7] Berger, E. H. (1991). Parents as partners in education: The school and home working together. New York: Macmillan.

[8] Caspe, M. S. (2003). How teachers come to understand families. School Community Journal, 13(1), 115-131.

[9] Chavkin, N.F., \& Gonzalez, D.L. (1995). Forging partnerships between Mexican American parents and the schools. West Virginia: ERIC Clearinghouse on Rural Education and Small Schools. (ERIC Document Reproduction Service No. ED388489).

[10] Clark, R. M. (1987). School policies for homeschool partnerships and student learning: Issues for policy makers and program planners. Paper presented at the annual meeting of the American Educational Research Association, Washington, DC.

[11] Corsi-Bunker, A. (2010). Guide to the education system in the United States: American education system. Minneapolis, MN: International Student \& Scholar Services, University of Minnesota.

[12] Costas, M. (1991). Hispanic Parental Involvement. M.S. Practicum, Nova University. ED 339462.

[13] Davern, L. (2004). School-to-home notebooks: What parents have to say. Teaching Exceptional Children, 36(5), 22-27. doi: https://journals.sagepub.com/doi/pdf/10.1177/004005990403600503

[14] Fauvelle, L. (2020, October 26). Qualitative research: 3 types of interview. IntoTheMinds. Retrieved from https://www.intotheminds.com/blog/en/qualitative-research-3-types-of-interview/

[15] Gibson, M.A. (2002). The new Latino diaspora and educational policy: Education in the new Latino diaspora: Policy and the politics of identity. Westport, CT: Ablex Publishing.

[16] Goodwin, A. P., \& Jiménez, R. (2016). Translate. The Reading Teacher, 69(6), 621-625.

[17] Google Limited Liability Company. (2021). Google translate. Retrieved from https://translate.google.com/ 
[18] Google Limited Liability Company. (2021). Translate a bilingual conversation (Computer). Retrieved from https://support.google.com/translate/answer/6142474?co=GENIE.Platform\%3DDesktop\&hl=en\&oco=0\#zippy=\%2Clanguages-you-canhave-a-conversation-in

[19] Google Limited Liability Company. (2021). Translate a bilingual conversation (Languages you can have a conversation in). Retrieved from https://support.google.com/translate/answer/6142474?co=GENIE.Platform\%3DAndroid\&hl=en\&oco=0\#zippy=\%2Clanguages-you-canhave-a-conversation-in

[20] Graham-Clay, S. (2005). Communicating with parents: Strategies for teachers. School Community Journal, 16, 117-129.

[21] Ho, L.H., Hung, C.L., \& Chen, H.C. (2013). Using theoretical models to examine the acceptance behavior of mobile phone messaging to enhance parent-teacher interactions. Computers \& Education, 61, 105-114. doi: http://dx.doi.org/10.1016/j.compedu.2012.09.009

[22] Indeed Career Guide. (2021, January 19). Four types of communication and how to improve them. Retrieved from https://www.indeed.com/career-advice/career-development/types-of-communication

[23] Keyton, J. (2010). Case studies for organizational communication: Understanding communication processes. New York, NY: Oxford University Press.

[24] Lake, V. E., \& Beisly, A. H. (2019). Translation apps: Increasing communication with dual language learners. Early Childhood Education Journal, 47, 489-496.

[25] LaRocque, M., Kleiman, I., \& Darling, S. M. (2011). Parental involvement: The missing link in school achievement. Preventing School Failure, 55(3), 115-122.

[26] Lawal, A. (2020). Equitable educational opportunities in K-12 schools: West African and U.S. public schools compared. Journal of Education. doi: https://journals.sagepub.com/doi/abs/10.1177/0022057420966765

[27] Lim, N., O'Reilly, M. F., Londono, F. V., \& Russell-George, A. (2020). Overcoming language barriers between interventionists and immigrant parents of children with autism spectrum disorder. Journal of Autism and Developmental Disorders. doi: https://doi.org/10.1007/s10803$\underline{020-04754-3}$

[28] Lim, N., O'Reilly, M. F., Sigafoos, J., Ledbetter-Cho, K., \& Lancioni, G. E. (2019). Should Heritage Languages be Incorporated into Interventions for Bilingual Individuals with Neurodevelopmental Disorders? A Systematic Review. Journal of Autism and Developmental Disorders, 49(3), 887-912. Doi:10.1007/s10803-018-3790-8.

[29] Liu, M., Navarrete, C., \& Wivagg, J. (2014). Potentials of mobile technology for K-12 Education: An investigation of iPod touch use for English language learners in the United States. Journal of Educational Technology \& Society, 17(2), 115-126.

[30] Lunenburg, F. C. (2010). Communication: The process, barriers, and improving effectiveness. Schooling, 1(1), 1-10.

[31] Merkley, D., Schmidt, D., Dirksen, C., \& Fulher, C. (2006). Enhancing parent-teacher communication using technology: A reading improvement clinic example. Contemporary Issues in Technology and Teacher Education, 6(1),11-42.

[32] Microsoft Corporation. (2021). Conversations - Microsoft translator. Retrieved from https://translator.microsoft.com/

[33] Microsoft Corporation. (2021). Languages. Retrieved from https://www.microsoft.com/en-us/translator/languages/

[34] Microsoft Corporation. (2021). Microsoft translator. Retrieved from https://www.microsoft.com/en-us/translator/

[35] Microsoft Corporation. (2021). Microsoft translator for education. Retrieved from https://www.microsoft.com/en-us/translator/education/

[36] Microsoft Corporation. (2021). Parent-teacher conferences: Tips for using the multi-device conversation feature. Retrieved from https://www.microsoft.com/en-us/translator/education/parent-teacher-conferences/\#tech

[37] Microsoft Corporation. (2021). Using Microsoft teams and Microsoft translator to host a multilingual parent-teacher conference: Instructions for teachers. Retrieved from https://www.microsoft.com/en-us/translator/education/microsoft-teams-multilingual-meeting/

[38] Ozmen, F., Akuzum, C., Zincirli, M., \& Selcuk, G. (2016). The communication barriers between teachers and parents in primary schools. Eurasian Journal of Educational Research, 66, 27-46. doi: http://dx.doi.org/10.14689/ejer.2016.66.2

[39] Perozzi, J. A., \& Sanchez, M. L. C. (1992). The effect of instruction in L1 on receptive acquisition of L2 for bilingual children with language delay. Language, Speech, and Hearing Services in Schools, 23(4), 348-352.

[40] Poza, L., Brooks, M. D., \& Valdes, G. (2014). Entre Familia: Immigrant parents' strategies for involvement in children's schooling. School Community Journal, 24(1), 119-148.

[41] Preciado, Y. (2014). Communication tools for teachers: A guide for improving teacher-parent communication. [Thesis, California State University]. Retrieved from https://www.academia.edu/30181739/Communication Tools for Teachers A Guide for Improving Teacher Parent Communication

[42] Prince, J. (2017). English language learners in a digital classroom. CATESOL Journal, 29(1), 51-73.

[43] Quiocho, A. M. L., \& Daoud, A. M. (2006). Dispelling myths about Latino parent participation in schools. The Educational Forum, 70(3), 255267.

[44] Rainie, L. (2013). Cell phone ownership hits $91 \%$ of adults. Pew Research Center. Retrieved from http://www.pewresearch.org/facttank/2013/06/06/cell-phone-ownership-hits-91-of-adults

[45] Rainie, L., \& Smith, A. (2013). Tablet and E-reader ownership update. Pew Research Center. Retrieved from http://www.pewinternet.org/2013/10/18/tablet-and-ereader-ownership-update/

[46] Rogers, R. R. H., \& Wright, V. H. (2008). Assessing technology's role in communication between parents and middle schools. Electronic Journal for the Integration of Technology in Education, 7, 36-58. doi: http://citeseerx.ist.psu.edu/viewdoc/summary?doi=10.1.1.484.6298

[47] Scribner, J. D., Young, M.D., \& Pedroza, A. (1999). Building collaborative relationships with parents. In P. Reyes, J.D. Scribner, \& A.P. Scribner (Eds.), Lessons from high-performing Hispanic schools: Creating learning communities. New York: Teachers College Press.

[48] Smith, A. (2013). 56\% of American adults are now smartphone owners. Pew Research Center. Retrieved from http://pewinternet.org/Reports/2013/Smartphone-Ownership-2013/Findings.aspx

[49] Smith, J. E. (2005). Factors that inhibit school involvement of Hispanic parents. [Dissertation, Oklahoma State University]. SHAREOK. Retrieved from https://shareok.org/handle/11244/7582

[50] Smith, J., Stern, K., \& Shatrova, Z. (2008). Factors inhibiting Hispanic parents' school involvement. The Rural Educator, Winter Edition, 1-13. Retrieved from https://files.eric.ed.gov/fulltext/EJ869288.pdf 
[51] Tyson, S.D. (2020). Exploring parent-teacher communication through technology: A case study. [Dissertation, Northcentral University]. ProQuest. Retrieved from https://search.proquest.com/openview/351f649e74285490f3f003b813539e66/1?pqorigsite $=$ gscholar \&cbl $=18750 \&$ diss $=y$

[52] Voiance. (2021). How interpretation should be: What can large-scale interpreter contact centers do for your multilingual support program? Retrieved from https://interpret.voiance.com/

[53] Voogt, J., \& Roblin, N. P. (2010). $27^{\text {st }}$ century skills: Discussion paper. Kennisnet: University of Twente. Retrieved from https://www.voced.edu.au/content/ngv\%3A56611

[54] Williams, V. I., \& Cartledge, G. (1997). Passing notes - To parents. Teaching Exceptional Children, 30(1), 30-34. doi: https://journals.sagepub.com/doi/10.1177/004005999703000106

[55] Yi, Y., \& Choi, J. (2015). Teachers' views of multimodal practices in K-12 classrooms: Voices from teachers in the United States. TESOL Quarterly, 49(4), 838-847.

[56] Zarate, M. E. (2007). Understanding Latino parental involvement in education: Perceptions, expectations, and recommendations. The Tomas Rivera Policy Institute. Retrieved from https://eric.ed.gov/?id=ED502065 